\title{
Effect of liquid medium on shoots amplification, in vitro flowering and ex vitro rooting of Oldenlandia umbellata L. - A dye yielding medicinal herb
}

\author{
Revathi Jayabal, Manokari Mani, Latha Rasangam, Priyadharshini Selvam, Mahipal Singh Shekhawat*
}

Department of Botany, Kanchi Mamunivar Center for Postgraduate Studies, Puducherry - 605 008, India

Received 4th December 2018 / Accepted 23rd January 2019

\begin{abstract}
Oldenlandia umbellata L. gains importance due to its medicinal properties and the presence of anthraquinones based natural dyes in the roots. Present study describes the effect of Murashige and Skoog's (MS) liquid medium (full strength) on in vitro regeneration, flower bud induction and ex vitro rooting in O. umbellata. Shoot segments with 2-3 nodes (each node with 2 axillary buds) served as explants for establishment of cultures. The liquid medium augmented with $2.0 \mathrm{mg} \mathrm{L}^{-1}$ 6-benzylaminopurine (BAP) with additives (50 $\mathrm{mg} \mathrm{L}^{-1}$ of ascorbic acid and $25 \mathrm{mg} \mathrm{L}^{-1}$ each of arginine, adenine sulphate and citric acid) was effective for shoot bud induction (6.4 \pm 0.19 shoots per explant within 2-3 weeks). The shoots were further multiplied (89.3 \pm 1.07 shoots, $2-3$ weeks) when the shoot clusters obtained from the culture initiation directly transferred to the full-strength MS liquid medium incorporated with $1.0 \mathrm{mg} \mathrm{L}^{-1} \mathrm{BAP}$ and $0.5 \mathrm{mg} \mathrm{L}^{-1}$ indole-3 acetic acid (IAA) with additives. Flower buds were induced (12.0 \pm 0.15 buds per shoot) when the shoots were cultured on $1.0 \mathrm{mg} \mathrm{L}^{-1} \mathrm{BAP}$ and kinetin (Kin, 6-furfurylaminopurine) and $0.5 \mathrm{mg}$ $\mathrm{L}^{-1}$ of IAA at $45 \mu \mathrm{mol} \mathrm{m}{ }^{-2} \mathrm{~s}^{-1}$ SFPD (Spectral Flux Photon Density) light intensity for 14/10h (light/dark) photoperiod. The adventitious roots were induced on 1/4 strength MS medium supplemented with 1.5 $\mathrm{mg} \mathrm{L}^{-1}$ indole-3 butyric acid (IBA). Ex vitro rooting was achieved (16.0 \pm 0.53 roots per shoot) by pulse treatment of the shoots with $300 \mathrm{mg} \mathrm{L}^{-1} \mathrm{IBA}$ for $2 \mathrm{~min}$. The in vitro produced plantlets were acclimatized in the greenhouse and finally translocated to the in vivo conditions with $93 \%$ success rate. This is the foremost (use of liquid MS medium) and cost-effective method for large scale multiplication of $O$. umbellata.
\end{abstract}

Keywords: Acclimation, ex vitro rooting, in vitro flowering, liquid medium, Oldenlandia umbellata

\section{INTRODUCTION}

Oldenlandia umbellata $\mathrm{L}$. is a natural dye yielding plant of the family Rubiaceae. There are ten synonyms of this plant viz. Gerontogea umbellata (L.) Cham. \& Schltdl., Hedyotis umbellata Lam., H. brevicalys Sivar., Biju \& P. Mathew, H. indica Roem. \& Schult., H. linarifolia R.Br. ex Wall., H. puberula (G.Don) R.Br. ex Arn., H. umbellata (L.) Lam., H. wightii (Hook. f.) K.K.N.Nair, H. wightii (Hook. f.) Sivar., Biju \& P. Mathew and O. puberula G. Don (The Plant List, 2013). It is a small, prostrate, profusely branched perennial herb; native to the Indian subcontinent but distributed in the tropical and subtropical regions such as Burma, Sri Lanka, Cambodia, Indonesia, India, Pakistan and the west tropical Africa (Siva, 2007). The plant is commonly known as Indian Madder plant, Chay root and Shaya (Yoganarasimhan and Chelladurai, 2000).

Ethnopharmacological and medicinal potential of this species are explored by the tribal

*Author for correspondence: Mahipal Singh Shekhawat, Department of Botany, Kanchi Mamunivar Center for Postgraduate Studies, Puducherry 605 008, India. Email - smahipal3@gmail.com 
people and ethnic communities of India and China (Yoganarasimhan and Chelladurai, 2000). Traditionally, the leaves and roots of $O$. umbellata were used in the treatment of various ailments (Samy et al., 2008). The roots are used to extract chay-root red dye for calico printing and coloring of fur and silk fabrics from centuries (Siva, 2007).

Owing to over exploitation of $O$. umbellata for its roots by the pharmaceutical companies to get herbal drugs (phenolic compounds and their derivatives) and to harvest anthraquinone pigments (red dye), the population of this plant has been depleted (due to uprooting of entire plant system) in the wild (Siva et al., 2012). The natural propagation of this plant is only by seeds and the plants are harvested before seeds setting. Therefore, there is a need of alternate methods of propagation for conservation of this plant species (Krishnan and Siril, 2015). Tissue culture techniques offer powerful tool for large-scale production of important plants which could help in conservation of medicinal plants.

Some reports are available on the in vitro studies and biosynthesis of secondary metabolites from $O$. umbellata, but all the researchers used agar-agar as gelling agent (Siva et al., 2009, 2012; Shekhawat et al., 2012; Kumar et al., 2014; Krishnan and Siril, 2015, 2016, 2017). Agar-agar is a conventional gelling agent used in tissue culture experiments and has been reported to possess certain disadvantages in differentiation and growth of the cultures. Agar powder increases the viscosity of the medium and slows down the nutrients intake by the cultures which affect the growth of plantlets (Kuria et al., 2008). Moreover, the gelling agents in plant tissue culture media may constitute about $70 \%$ of production cost (Mohamed et al., 2010). Attempts were made with the other alternatives of agar to reduce this cost, but success was always questionable (Babbar and Jain, 2006). The use of liquid medium for in vitro propagation is very effective in proliferation of shoots and adventitious roots which reduce time, energy and cost of production of plantlets (Mehta et al., 2014).

In vitro flower induction explains the fundamental mechanism of transition phase from vegetative phase to the reproductive phase and it could further help to study the physiology of in vitro flowering process (Cheruvathur et al., 2015). Rooting and acclimatization can be achieved concurrently through ex vitro rooting method. Ex vitro rooting produces better adventitious roots which can again reduce the time; cost and labor input during in vitro rooting (Ranaweera et al., 2013).

Therefore, experiments were conducted for the first time to explore the effect of liquid medium in bud breaking, shoots multiplication, in vitro flowering and ex vitro rooting of $O$. umbellata.

\section{MATERIALS AND METHODS}

Plant materials and surface sterilization. Oneyear old O. umbellata plants were collected from the natural habitats of the east coast of India (Puducherry Union Territory), the Coromandel coast $\left(11.9416^{\circ} \mathrm{N}, 79.8083^{\circ} \mathrm{E}\right)$, maintained in greenhouse and identified by the Institut Français de Pondichéry (IFP), Puducherry (Accession number: HIFP 26744). The nodal segments (explants) of 3-4 cm in length (bearing 2-3 nodes, each node with 2 axillary buds) were collected at the flowering stage. Initially, the explants were treated with $0.1 \%(\mathrm{w} / \mathrm{v})$ broad spectrum antifungal agent Bavistin (BASF India Ltd., India) for 5-7 min and surface sterilization was achieved with $0.1 \%(\mathrm{w} / \mathrm{v})$ mercuric chloride (Hi-Media, India) solution for 4-5 $\mathrm{min}$ and finally rinsed (five times) with sterilized distilled water under aseptic conditions.

Nutrient medium and culture conditions. Full strength Murashige and Skoog's (MS) medium (Murashige and Skoog, 1962) incorporated with $3 \%$ sucrose, additives $\left(50 \mathrm{mg} \mathrm{L}^{-1}\right.$ of ascorbic acid and $25 \mathrm{mg} \mathrm{L}^{-1}$ each of arginine, adenine sulphate and citric acid) (after Patel et al., 2014) devoid of agar-agar (liquid medium) was used for regeneration of cultures in this study. The $\mathrm{pH}$ of the medium was attuned to $5.8 \pm 0.02$ with $1 \mathrm{~N} \mathrm{HCl}$ or $\mathrm{NaOH}$ before autoclaving at $108 \mathrm{kPa}$ pressure and $120^{\circ} \mathrm{C}$ temperature for $15 \mathrm{~min}$. The culture flasks were kept on a gyratory shaker at $100 \mathrm{rpm}$ (Technico Pvt. Ltd, Chennai, India), incubated at $25 \pm 2{ }^{\circ} \mathrm{C}$ temperature under $12 / 12 \mathrm{~h}$ (light/dark) photoperiod with light intensity of $40-50 \mu \mathrm{mol}$ $\mathrm{m}^{-2} \mathrm{~s}^{-1}$ Spectral Photon Flux Density (SPFD) provided by cool white fluorescent lamps of 40 Watts each (Philips India Ltd, New Delhi). The $250 \mathrm{~mL}$ Borosilicate culture flasks procured from 
the Technico Pvt. Ltd., Chennai, India were used in this study. Twenty-five ml liquid MS medium was poured in each culture vessel and the vessels were closed by cotton plugs before autoclaving.

Induction and proliferation of shoots. The sterilized nodal shoot segments (explants) were inoculated in full strength liquid MS medium (one explant per vessel) without trimming the cut ends. Liquid MS medium fortified with different concentrations of cytokinins, BAP (6benzylaminopurine) and Kin (6furfurylaminopurine) ranging from 0.5 to $3.0 \mathrm{mg}$ $\mathrm{L}^{-1}$ (Sigma-Aldrich, St. Louis, USA) alone or in combinations were used for the induction of shoots from nodal explants. The cultures were transferred to the fresh medium after every 2 weeks. The in vitro regenerated shoots with optimized length were segmented leaving 3-4 nodes and subcultured on MS medium containing various concentrations of BAP $\left(0.1\right.$ to $\left.2.5 \mathrm{mg} \mathrm{L}^{-1}\right)$ combined with various concentrations $(0.25$ to $0.75 \mathrm{mg} \mathrm{L}^{-1}$ ) of IAA (indole-3-acetic acid) for proliferation of shoots. The shoots were further multiplied by repeated transfer of mother explants and subculturing of in vitro shoots. The cultures on MS medium devoid of growth regulators were treated as control.

In vitro flower buds induction. The in vitro produced shoots of 3-4 $\mathrm{cm}$ in length were excised and subcultured on full strength liquid MS medium augmented with various concentrations ( 0.5 to $2.0 \mathrm{mg} \mathrm{L}^{-1}$ ) of BAP and Kin combined with IAA ( 0.1 to $\left.0.75 \mathrm{mg} \mathrm{L}^{-1}\right)$ for in vitro flower bud induction. Various parameters such as percentage response and average number of flower buds were recorded after 4-5 weeks of incubation. The cultures were maintained at $25 \pm 2{ }^{\circ} \mathrm{C}$ under various photoperiod regimes $(10 / 14$ to $16 / 8 \mathrm{~h}$ per day light/dark) with light intensity of 40-50 $\mu \mathrm{mol}$ $\mathrm{m}^{-2} \mathrm{~s}^{-1}$ SPFD provided through white fluorescent tubes.

In vitro rooting of the shoots. Healthier shoots were separated from the multiplied shoot clumps and transferred to various strengths of nutrient medium (full, $1 / 2$ and $1 / 4$ strengths of MS liquid media) augmented with auxins [IAA, IBA (indole3 -butyric acid) and NAA ( $\alpha$-naphthalene acetic acid)] at various concentrations (1.0-4.0 $\left.\mathrm{mg} \mathrm{L}^{-1}\right)$ for induction of roots. The cultures were initially incubated under diffused light for 2-3 days thereafter shifted to the in vitro culture environment, and maintained at the light intensity of $40-45 \mu \mathrm{mol} \mathrm{m}^{-2} \mathrm{~s}^{-1}$ SPFD.

EX vitro rooting and hardening of plantlets. The end base of the shoots was pulsed with various types and concentrations of auxins (IAA, IBA and NAA at 50-500 $\mathrm{mg} \mathrm{L}^{-1}$ ) for various time durations (1-5 min) for ex vitro rooting. The treated shoots were transplanted into $1.5-2.0 \mathrm{~cm}$ deep in paper cups (size $150 \mathrm{~mL}$ ) containing $50 \mathrm{~g}$ sterilized soilrite ${ }^{\circledR}$ (Keltech Energy Limited, Bangalore, India) without any antibiotic treatment. Shoots were moistened with $15 \mathrm{~mL}$ $1 / 4$ strength MS macro salts solution by the intermission of one week to evade wilting. The set up was capped by perforated transparent polythene cups and maintained in greenhouse under high relative humidity $(80-90 \% \mathrm{RH})$ and $28 \pm 2{ }^{\circ} \mathrm{C}$ temperature conditions. The caps were gradually removed over a period of two to four weeks. These plantlets were transferred to the nursery poly bags containing organic manure, sand and red soil $(1: 1: 1 ; \mathrm{w} / \mathrm{w})$ and maintained for 5 weeks. The same plants were next shifted to the earthen pots filled with garden soil, red soil and vermi-compost $(2: 2: 1 ; \mathrm{w} / \mathrm{w})$, irrigated with tap water and retained in greenhouse for another one and half months for proper hardening.

Experimental design, data collection and statistical analysis. The experiments were laid out in completely randomized block design (CRBD) (Compton and Mize, 1999), conducted with 20 explants for each treatment and repeated thrice (triplicates). The observations on the response, number and length of shoots and roots were recorded at 4 weeks time interval. The data were subjected to the standard error of the mean and single factor analysis of variance (one-way ANOVA). The significance of differences among mean values was carried out using Duncan's Multiple Range Test (DMRT) at $P<0.05$ using SPSS software, version 16.0 (SPSS Inc., Chicago, USA). The results were expressed as Mean \pm Standard Error.

\section{RESULTS AND DISCUSSION}


Significant improvements were observed in terms of production of shoots with maximum number of nodes and roots with rapid organ developments (within 2 weeks) due to the adoption of liquid MS medium in present study.

Axillary bud emergence from the explants. All the explants yielded shoots on MS liquid medium with various treatments of cytokinins (Figure 1a). The MS medium supplemented with $2.0 \mathrm{mg} \mathrm{L}^{-1}$ BAP generated highest number of axillary buds $(6.4 \pm 0.19$ shoots per explant with $4.0 \pm 0.21 \mathrm{~cm}$ mean length) within 2-3 weeks from the nodal explants (Table 1, Figures 1b and 1c). Liquid MS medium combined with BAP alone significantly enhanced shoots formation from the explants as compared to the other hormonal treatments tested. The MS medium augmented with Kin at $1.5 \mathrm{mg} \mathrm{L}^{-1}$ produced $4.2 \pm 0.38$ shoots. The length of the $O$. umbellata shoots was better in liquid medium as compared to semisolid medium used in previous studies (Shekhawat et al., 2012). The role of liquid medium in axillary bud induction is first time reported in this species. Liquid culture system is advantageous over to the agar gelled medium due to rapid uptake of nutrients by the cells and tissues and minimum negative effect of phenolics leach outs which ultimately enhance the growth of cultured shoots and roots (AlKhateeb and Alturki 2014). Kumar et al. (2014) induced 6 shoots (3.5 cm in length) on agar gelled MS medium containing $3.0 \mathrm{mg} \mathrm{L}^{-1}$ BAP using shoot tip explants. Krishnan and Siril (2015) observed vitrified shoots with crowning of scaly leaves when nodal explants cultured on agar gelled MS medium with high concentration of 6benzyladenine (BA).

\section{Proliferation of shoots in liquid MS medium.}

The number of shoots was enhanced about 15 folds (from initiation stage) when the regenerated shoots and mother explants were subcultured on MS liquid medium composed of $1.0 \mathrm{mg} \mathrm{L}^{-1} \mathrm{BAP}$ and $0.5 \mathrm{mg} \mathrm{L}^{-1} \mathrm{IAA}$ with additives. The maximum shoot numbers $(89.3 \pm 1.07)$ with average length of $12.5 \pm 0.30 \mathrm{~cm}$ were obtained using this media combination (Table 2, Figure 1d). It has been reported that cytokinin and auxin are the major plant growth regulators of core cell cycle components (Takatsuka and Umeda, 2014). Shekhawat et al. (2012) reported shedding of leaves of $O$. umbellata on semisolid media incorporated with optimized growth regulators. It was observed that liquid media facilitated the production of quality shoots in terms of shoot numbers, shoot length and thickness as compared to agar gelled medium. All the shoots appeared healthy in liquid medium and did not display any symptoms of hyperhydration or vitrification in this experiment. Pati et al. (2005) also reported that the liquid medium enhanced rate of shoots multiplication with complete elimination of vitrification in Rosa damascena and R. bourboniana. Similar results reported in propagation of apple by Mehta et al. (2014).

In vitro flowering. Healthy and long shoots (4-5 $\mathrm{cm})$ were cultured on MS medium augmented with combination of cytokinins and auxin resulted in development of terminal and axial congested umbelliform inflorescence. Among the growth regulators tested, the combination of full-strength MS medium containing $1.0 \mathrm{mg} \mathrm{L}^{-1} \mathrm{BAP}$ and Kin $+0.5 \mathrm{mg} \mathrm{L}^{-1}$ of IAA at $45 \mu \mathrm{mol} \mathrm{m}{ }^{-2} \mathrm{~s}^{-1}$ SFPD light intensity for $14 / 10 \mathrm{~h}$ (light/dark) photoperiod induced the highest number of flower buds in O. umbellata (Table 3). Three inflorescences per shoot were observed and $12.0 \pm 0.15$ flower buds per inflorescence were emerged when the shoots grown on this medium (Figure 1e). The in vitro raised flower buds gradually opened after 2-3 days and expressed similar physical characters as of the mother plants in nature. Flowers were distylous with short pedicel, white corolla, green calyx and glabrous (Figure 1f). In vitro flower bud induction is promoted by the plant growth regulators and photoperiods (Taylor et al., 2005). Recently, Behera et al. (2017) reported in vitro flowers from embryogenic calli of $O$. umbellata on MS semisolid medium. Successful in vitro and ex vitro flowering is reported to be determined by various intrinsic and extrinsic factors such as florigen coupled with time duration and meristematic activity (Zeevaart, 2006). The results could be used for further analysis of ontogeny of flowers in plants.

In vitro rooting of the proliferated shoots. Liquid MS medium with IBA played an important role in adventitious roots induction from the 
shoots (Thakur et al., 2018). The development and proliferation of roots $(100 \%)$ were more rapid in $1 / 4^{\text {th }}$ strength of MS liquid medium (Table 4). Quarter strength MS medium with $1.5 \mathrm{mg} \mathrm{L}^{-1} \mathrm{IBA}$ resulted in the emergence of $24.2 \pm 0.47$ roots with the mean length of $6.1 \pm 0.22 \mathrm{~cm}$ within 3 weeks (Figure 1g). Comparatively, IAA detected as the weakest hormone in the root induction and NAA ranked second next to the IBA. The previous reports on the role of auxins in rooting of shoots of $O$. umbellata are contradictory to the present findings. Siva et al. (2012) reported that higher concentration of NAA in semisolid MS medium had better effect in induction of roots and production of anthraquinone pigments as compared to IBA and IAA from the roots of $O$. umbellata. Enhanced induction and proliferation of adventitious roots in the liquid medium with auxins support the concept of the quick absorption of nutrients from the liquid media than the semisolid medium.

\section{Ex vitro rooting and hardening of the} plantlets. Comparatively IBA was found most suitable for ex vitro root induction than IAA and NAA. The shoots pulsed with $300 \mathrm{mg} \mathrm{L}^{-1}$ IBA for 2 min exhibited $100 \%$ rooting response. Maximum 16.0 \pm 0.53 roots with $4.2 \pm 0.22 \mathrm{~cm}$ average length were induced from the cut end of the shoots with IBA at $300 \mathrm{mg} \mathrm{L}^{-1}$ (Table 5, Figure 1h). Krishnan and Siril (2015) observed 14.03 roots/shoot when the shoots were treated with IBA. The roots induced via this method were superior to the in vitro roots in terms of thickness and firmness, which helped in hardening processes in order to improve the survival percentage of $O$. umbellata plantlets in the field conditions. The results are in agreed with the reports of Patel et al. (2014) in Caralluma edulis and Ranaweeraa et al. (2013) in Camellia sinensis. According to the cost estimation on ex vitro rooting experiments, it is revealed that the plant production cost can be reduced up to $70 \%$ in development of a micropropagation protocol using ex vitro rooting technique (Ranaweeraa et al., 2013).

The rooted shoots were placed on the paper cups containing soilrite ${ }^{\circledR}$ and uphold for 5 weeks in the greenhouse (Figure 2a). Further, the greenhouse hardened plantlets were transferred to nursery poly-bags containing organic manure, sand and red soil $(1: 1: 1 ; \mathrm{w} / \mathrm{w})$ (Figure $2 \mathrm{~b})$. The plantlets were shifted to earthen pots filled with garden soil, red soil and vermi-compost (2:2:1; $\mathrm{w} / \mathrm{w})$ after 4 weeks and finally planted in the natural habitat in another 4-5 weeks (Figures 2c and $2 d$ ). About $93 \%$ plantlets survived in the field conditions after 6 months of transfer. This rate of survival is superior to the earlier reports in this plant. Krishnan and Siril (2015) achieved 81.3\% survival rate in quercetin induced shoots of $O$. umbellata.

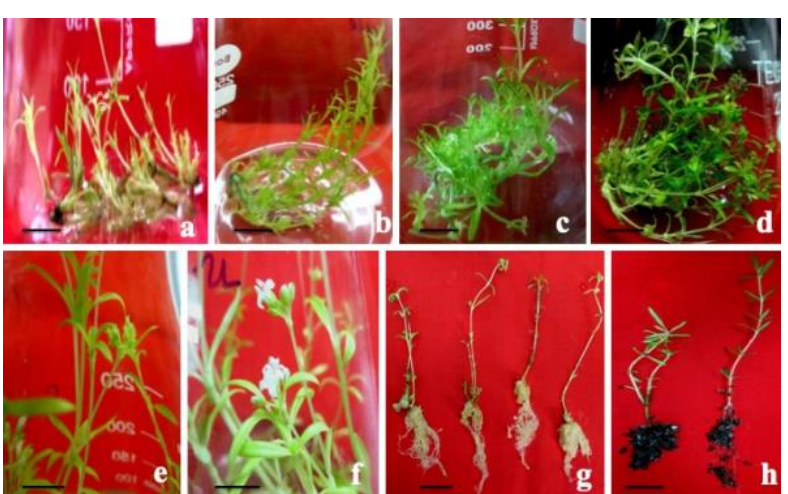

Figure 1. In vitro propagation of O. umbellata L. (a) Induction of shoots from nodal explants in liquid MS medium containing $2.0 \mathrm{mg} \mathrm{L}^{-1} 6-\mathrm{BAP}$, (b and c) Elongation of shoots after subculture to fresh liquid MS medium after 2-3 weeks, (d) Proliferation of shoots after 2-3 weeks on MS liquid medium + BAP $1.0 \mathrm{mg} \mathrm{L}^{-1}$ and IAA $0.5 \mathrm{mg}$ $\mathrm{L}^{-1}$, (e) Flower buds induction (axial and terminal) on MS medium augmented with $1.0 \mathrm{mg} \mathrm{L}^{-1} \mathrm{BAP}$ and $0.5 \mathrm{mg} \mathrm{L}^{-1}$ each of Kin and IAA at $45 \mu \mathrm{mol}$ $\mathrm{m}^{-2} \mathrm{~s}^{-1}$ light intensity, (f) Formation of complete flowers in vitro after 2-3 days of formation of inflorescence, $(\mathrm{g})$ In vitro root induction within 3 weeks after subculture in $1 / 4$ MS medium containing $1.5 \mathrm{mg} \mathrm{L}^{-1} \mathrm{IBA}$, (h) Ex vitro rooted shoots in soilrite ${ }^{\circledR}$ after 3-4 weeks. (Scale bar - 1 $\mathrm{cm}$ ) 
Table 1. Effect of cytokinins (BAP and Kin) on shoots induction from nodal stem segments of Oldenlandia umbellata after 3weeks of cultures in MS liquid medium.

\begin{tabular}{|c|c|c|c|c|}
\hline \multicolumn{2}{|c|}{ Cytokinins ( $\left.\mathrm{mg} \mathrm{L}^{-1}\right)$} & \multirow[t]{2}{*}{ Response (\%) } & \multirow{2}{*}{$\begin{array}{c}\text { Shoots number } \\
\text { (Mean } \pm \text { SE) }\end{array}$} & \multirow{2}{*}{$\begin{array}{l}\text { Shoots length } \\
\text { (Mean } \pm \mathrm{SE})\end{array}$} \\
\hline BAP & Kin & & & \\
\hline 0.0 & 0.0 & 0 & $0.0 \pm 0.00^{\mathrm{a}}$ & $0.0 \pm 0.00^{\mathrm{a}}$ \\
\hline 0.5 & - & 62 & $2.0 \pm 0.23^{c}$ & $1.9 \pm 0.15^{\mathrm{b}}$ \\
\hline 1.0 & - & 75 & $2.7 \pm 0.18^{\mathrm{d}}$ & $2.5 \pm 0.30^{c}$ \\
\hline 1.5 & - & 91 & $4.0 \pm 0.39^{\mathrm{f}}$ & $3.1 \pm 0.16^{\mathrm{d}}$ \\
\hline 2.0 & - & 100 & $6.4 \pm 0.19^{\mathrm{h}}$ & $4.0 \pm 0.35^{\mathrm{f}}$ \\
\hline 2.5 & - & 94 & $5.1 \pm 0.47^{g}$ & $3.8 \pm 0.11^{\mathrm{e}}$ \\
\hline 3.0 & - & 80 & $3.9 \pm 0.24^{\mathrm{e}}$ & $3.0 \pm 0.20^{\mathrm{d}}$ \\
\hline- & 0.5 & 57 & $1.4 \pm 0.11^{b}$ & $1.4 \pm 0.26^{\mathrm{b}}$ \\
\hline- & 1.0 & 64 & $2.0 \pm 0.29^{c}$ & $2.0 \pm 0.41^{\mathrm{c}}$ \\
\hline- & 1.5 & 89 & $4.2 \pm 0.38^{\mathrm{f}}$ & $3.6 \pm 0.11^{\mathrm{d}}$ \\
\hline- & 2.0 & 80 & $3.3 \pm 0.12^{\mathrm{e}}$ & $3.1 \pm 0.33^{\mathrm{d}}$ \\
\hline- & 2.5 & 76 & $3.0 \pm 0.20^{\mathrm{e}}$ & $2.7 \pm 0.27^{\mathrm{e}}$ \\
\hline- & 3.0 & 61 & $2.6 \pm 0.36^{\mathrm{d}}$ & $2.0 \pm 0.25^{\mathrm{c}}$ \\
\hline
\end{tabular}

Note: The values represented in corresponding column followed by same letters are not significantly different by DMRT at $p<0.05$.

Table 2. Combined effect of BAP and IAA on proliferation of multiple shoots in liquid MS medium after 2 weeks.

\begin{tabular}{cccc}
\hline \multicolumn{2}{c}{ Cytokinins $\left(\mathbf{m g ~ L}^{-1}\right)$} & Shoots number (Mean \pm SE) & Shoots length (Mean \pm SE) \\
\cline { 1 - 2 } BAP & Kin & & \\
\hline 0.0 & 0.0 & $00.0 \pm 0.00^{\mathrm{a}}$ & $0.00 \pm 0.00^{\mathrm{a}}$ \\
0.5 & 0.25 & $43.7 \pm 0.92^{\mathrm{b}}$ & $5.14 \pm 0.17^{\mathrm{b}}$ \\
1.0 & 0.25 & $61.0 \pm 1.00^{\mathrm{h}}$ & $7.15 \pm 0.97^{\mathrm{f}}$ \\
1.5 & 0.25 & $58.1 \pm 0.80^{\mathrm{f}}$ & $6.30 \pm 0.80^{\mathrm{e}}$ \\
2.0 & 0.25 & $53.4 \pm 0.77^{\mathrm{d}}$ & $6.00 \pm 0.11^{\mathrm{d}}$ \\
2.5 & 0.25 & $45.9 \pm 0.42^{\mathrm{c}}$ & $5.72 \pm 0.47^{\mathrm{c}}$ \\
0.5 & 0.5 & $60.0 \pm 0.29^{\mathrm{g}}$ & $9.36 \pm 0.39^{\mathrm{k}}$ \\
1.0 & 0.5 & $89.3 \pm 1.07^{\mathrm{h}}$ & $12.5 \pm 0.30^{\mathrm{n}}$ \\
1.5 & 0.5 & $80.0 \pm 1.39^{\mathrm{m}}$ & $10.0 \pm 0.73^{1}$ \\
2.0 & 0.5 & $71.6 \pm 1.18^{\mathrm{k}}$ & $9.14 \pm 1.00^{\mathrm{j}}$ \\
2.5 & 0.5 & $63.1 \pm 0.94^{\mathrm{i}}$ & $8.00 \pm 0.91^{\mathrm{h}}$ \\
0.5 & 0.75 & $60.3 \pm 0.65^{\mathrm{g}}$ & $7.63 \pm 0.59^{\mathrm{g}}$ \\
1.0 & 0.75 & $82.8 \pm 2.13^{\mathrm{e}}$ & $10.9 \pm 0.82^{\mathrm{m}}$ \\
1.5 & 0.75 & $74.2 \pm 1.10^{1}$ & $8.97 \pm 0.46^{\mathrm{i}}$ \\
2.0 & 0.75 & $69.9 \pm 0.49^{\mathrm{j}}$ & $8.05 \pm 0.50^{\mathrm{h}}$ \\
2.5 & 0.75 & $55.7 \pm 1.00^{\mathrm{e}}$ & $7.10 \pm 0.37^{\mathrm{f}}$ \\
\hline
\end{tabular}

Note: The values represented in corresponding column followed by same letters are not significantly different by DMRT at $p<0.05$. 
Table 3. Effect of cytokinins (BAP, Kin) and IAA in induction of flowers per inflorescence under 45 $\mu \mathrm{mol} \mathrm{m} \mathrm{m}^{-2} \mathrm{~s}^{-1}$ SFPD for $14 / 10 \mathrm{~h}$ (light/dark) photoperiod.

\begin{tabular}{ccc}
\hline $\begin{array}{c}\text { Conc. of BAP + Kin } \\
\left(\mathbf{m g ~ L}^{-1}\right)\end{array}$ & $\begin{array}{c}\text { Conc. of IAA } \\
\left(\mathbf{m g ~ L}^{-1}\right)\end{array}$ & $\begin{array}{c}\text { Number of flower buds } \\
(\text { Mean } \pm \text { SE) }\end{array}$ \\
\hline 0.00 & 0.00 & $0.0 \pm 0.00^{\mathrm{a}}$ \\
0.50 & 0.1 & $4.1 \pm 0.13^{\mathrm{b}}$ \\
0.75 & 0.1 & $4.8 \pm 0.28^{\mathrm{c}}$ \\
1.00 & 0.1 & $6.3 \pm 0.44^{\mathrm{i}}$ \\
1.50 & 0.1 & $6.0 \pm 0.37^{\mathrm{h}}$ \\
2.00 & 0.1 & $5.0 \pm 0.15^{\mathrm{d}}$ \\
0.50 & 0.5 & $6.9 \pm 0.11^{\mathrm{k}}$ \\
0.75 & 0.5 & $7.0 \pm 0.53^{1}$ \\
1.00 & 0.5 & $12.0 \pm 0.15^{\circ}$ \\
1.50 & 0.5 & $9.8 \pm 0.12^{\mathrm{n}}$ \\
2.00 & 0.5 & $5.1 \pm 0.71^{\mathrm{e}}$ \\
0.50 & 0.75 & $5.5 \pm 0.26^{\mathrm{g}}$ \\
0.75 & 0.75 & $6.7 \pm 0.59 \mathrm{j}$ \\
1.00 & 0.75 & $7.2 \pm 0.35^{\mathrm{m}}$ \\
1.50 & 0.75 & $6.0 \pm 0.72^{\mathrm{h}}$ \\
2.00 & 0.75 & $5.4 \pm 0.16^{\mathrm{f}}$ \\
\hline
\end{tabular}

Note: The values represented in corresponding column followed by same letters are not significantly different by DMRT at $p<0.05$.

Table 4. Effect of auxins (IAA, IBA and NAA) on in vitro root induction from the shoots on $1 / 4$ strength MS liquid medium.

\begin{tabular}{|c|c|c|c|c|c|}
\hline \multicolumn{3}{|c|}{ Auxins (mg L $\left.{ }^{-1}\right)$} & \multirow[t]{2}{*}{ Response (\%) } & \multirow{2}{*}{$\begin{array}{c}\text { Roots number } \\
(\text { Mean } \pm \text { SE) }\end{array}$} & \multirow{2}{*}{$\begin{array}{l}\text { Roots length } \\
(\text { Mean } \pm \text { SE) }\end{array}$} \\
\hline IAA & IBA & NAA & & & \\
\hline 0.0 & 0.0 & 0.0 & 00 & $0.0 \pm 0.00^{\mathrm{a}}$ & $0.0 \pm 0.00^{\mathrm{a}}$ \\
\hline 1.0 & - & - & 47 & $6.7 \pm 0.11^{\mathrm{c}}$ & $2.6 \pm 0.16^{\mathrm{b}}$ \\
\hline 1.5 & - & - & 62 & $7.0 \pm 0.39^{\mathrm{d}}$ & $3.0 \pm 0.45^{c}$ \\
\hline 2.0 & - & - & 68 & $8.5 \pm 0.35^{\mathrm{e}}$ & $3.8 \pm 0.22^{c}$ \\
\hline 2.5 & - & - & 81 & $8.0 \pm 0.72^{\mathrm{e}}$ & $4.1 \pm 0.39^{d}$ \\
\hline 3.0 & - & - & 70 & $7.2 \pm 0.41^{\mathrm{d}}$ & $4.3 \pm 0.15^{\mathrm{d}}$ \\
\hline 3.5 & - & - & 64 & $6.9 \pm 0.19^{c}$ & $3.0 \pm 0.24^{c}$ \\
\hline 4.0 & - & - & 59 & $6.4 \pm 0.25^{c}$ & $3.4 \pm 0.59^{c}$ \\
\hline- & 1.0 & - & 92 & $18.6 \pm 0.18^{g}$ & $5.7 \pm 0.25^{\mathrm{e}}$ \\
\hline- & 1.5 & - & 100 & $24.2 \pm 0.47^{\mathrm{h}}$ & $6.1 \pm 0.22^{f}$ \\
\hline- & 2.0 & - & 95 & $19.4 \pm 0.33^{g}$ & $5.5 \pm 0.37^{\mathrm{e}}$ \\
\hline- & 2.5 & - & 89 & $10.9 \pm 0.49^{\mathrm{f}}$ & $5.0 \pm 0.61^{\mathrm{e}}$ \\
\hline- & 3.0 & - & 83 & $8.3 \pm 0.82^{\mathrm{e}}$ & $4.6 \pm 0.26^{\mathrm{d}}$ \\
\hline- & 3.5 & - & 78 & $8.0 \pm 0.16^{\mathrm{e}}$ & $4.1 \pm 0.30^{\mathrm{d}}$ \\
\hline- & 4.0 & - & 70 & $7.5 \pm 0.22^{\mathrm{d}}$ & $3.5 \pm 0.23^{c}$ \\
\hline- & - & 1.0 & 50 & $7.8 \pm 0.10^{\mathrm{d}}$ & $3.2 \pm 0.27^{c}$ \\
\hline- & - & 1.5 & 66 & $8.5 \pm 0.32^{\mathrm{e}}$ & $3.7 \pm 0.30^{c}$ \\
\hline - & - & 2.0 & 79 & $9.2 \pm 0.67^{\mathrm{f}}$ & $4.9 \pm 0.32^{\mathrm{d}}$ \\
\hline- & - & 2.5 & 88 & $10.8 \pm 0.44^{\mathrm{f}}$ & $5.2 \pm 0.39^{\mathrm{e}}$ \\
\hline- & - & 3.0 & 75 & $8.6 \pm 0.19^{e}$ & $5.0 \pm 0.41^{\mathrm{e}}$ \\
\hline - & - & 3.5 & 70 & $6.0 \pm 0.61^{c}$ & $4.5 \pm 0.17^{\mathrm{d}}$ \\
\hline- & - & 4.0 & 67 & $5.1 \pm 0.36^{\mathrm{b}}$ & $3.9 \pm 0.64^{c}$ \\
\hline
\end{tabular}

Note: The values represented in corresponding column followed by same letters are not significantly different by DMRT at $p<0.05$. 
Table 5. Effect of auxins (IAA, IBA and NAA) on ex vitro rooting of in vitro raised shoots of Oldenlandia umbellata in Soilrite ${ }^{\circledR}$.

\begin{tabular}{|c|c|c|c|c|c|}
\hline \multicolumn{3}{|c|}{ Auxins (mg $\left.\mathrm{L}^{-1}\right)$} & \multirow[t]{2}{*}{ Response (\%) } & \multirow{2}{*}{$\begin{array}{l}\text { Roots number } \\
\text { (Mean } \pm \text { SE) }\end{array}$} & \multirow{2}{*}{$\begin{array}{l}\text { Roots length } \\
\text { (Mean } \pm \text { SE) }\end{array}$} \\
\hline IAA & IBA & NAA & & & \\
\hline 0 & 0 & 0 & 00 & $0.0 \pm 0.0^{\mathrm{a}}$ & $0.0 \pm 0.00^{a}$ \\
\hline 50 & - & - & 61 & $4.6 \pm 0.12^{\mathrm{b}}$ & $2.3 \pm 0.26^{\mathrm{b}}$ \\
\hline 100 & - & - & 74 & $5.9 \pm 0.26^{\mathrm{c}}$ & $2.8 \pm 0.39^{\mathrm{b}}$ \\
\hline 150 & - & - & 79 & $6.4 \pm 0.38^{\mathrm{d}}$ & $3.1 \pm 0.42^{c}$ \\
\hline 200 & - & - & 82 & $6.9 \pm 0.11^{\mathrm{d}}$ & $3.6 \pm 0.69^{c}$ \\
\hline 300 & - & - & 85 & $8.5 \pm 0.35^{\mathrm{f}}$ & $3.0 \pm 0.23^{c}$ \\
\hline 400 & - & - & 71 & $7.2 \pm 0.56^{\mathrm{e}}$ & $2.7 \pm 0.19^{\mathrm{b}}$ \\
\hline 500 & - & - & 63 & $6.7 \pm 0.42^{\mathrm{d}}$ & $2.0 \pm 0.36^{\mathrm{b}}$ \\
\hline- & 50 & - & 81 & $7.1 \pm 0.39^{\mathrm{e}}$ & $2.7 \pm 0.27^{\mathrm{b}}$ \\
\hline- & 100 & - & 87 & $8.9 \pm 0.26^{\mathrm{f}}$ & $3.5 \pm 0.11^{c}$ \\
\hline- & 150 & - & 93 & $9.4 \pm 0.55^{\mathrm{g}}$ & $3.8 \pm 0.20^{c}$ \\
\hline- & 200 & - & 95 & $12.6 \pm 0.60^{\mathrm{h}}$ & $4.0 \pm 0.39^{\mathrm{d}}$ \\
\hline- & 300 & - & 100 & $16.0 \pm 0.53^{j}$ & $4.2 \pm 0.22^{\mathrm{d}}$ \\
\hline- & 400 & - & 91 & $14.5 \pm 0.29^{\mathrm{i}}$ & $3.9 \pm 0.48^{c}$ \\
\hline- & 500 & - & 85 & $11.3 \pm 0.36^{\mathrm{h}}$ & $3.3 \pm 0.31^{\mathrm{c}}$ \\
\hline- & - & 50 & 73 & $5.5 \pm 0.72^{c}$ & $2.5 \pm 0.20^{\mathrm{b}}$ \\
\hline- & - & 100 & 79 & $7.2 \pm 0.53^{\mathrm{e}}$ & $3.1 \pm 0.39^{c}$ \\
\hline- & - & 150 & 84 & $7.7 \pm 0.26^{\mathrm{e}}$ & $3.3 \pm 0.18^{c}$ \\
\hline - & - & 200 & 89 & $8.5 \pm 0.45^{f}$ & $3.5 \pm 0.10^{c}$ \\
\hline- & - & 300 & 92 & $9.6 \pm 0.19^{g}$ & $3.9 \pm 0.26^{\mathrm{d}}$ \\
\hline - & - & 400 & 86 & $8.0 \pm 0.37^{\mathrm{f}}$ & $3.4 \pm 0.32^{c}$ \\
\hline - & - & 500 & 79 & $7.3 \pm 0.22^{\mathrm{e}}$ & $2.8 \pm 0.35^{\mathrm{b}}$ \\
\hline
\end{tabular}

Note: Data were recorded after 4 weeks in greenhouse conditions. The values represented in corresponding column followed by same letters are not significantly different by DMRT at $p<0.05$.
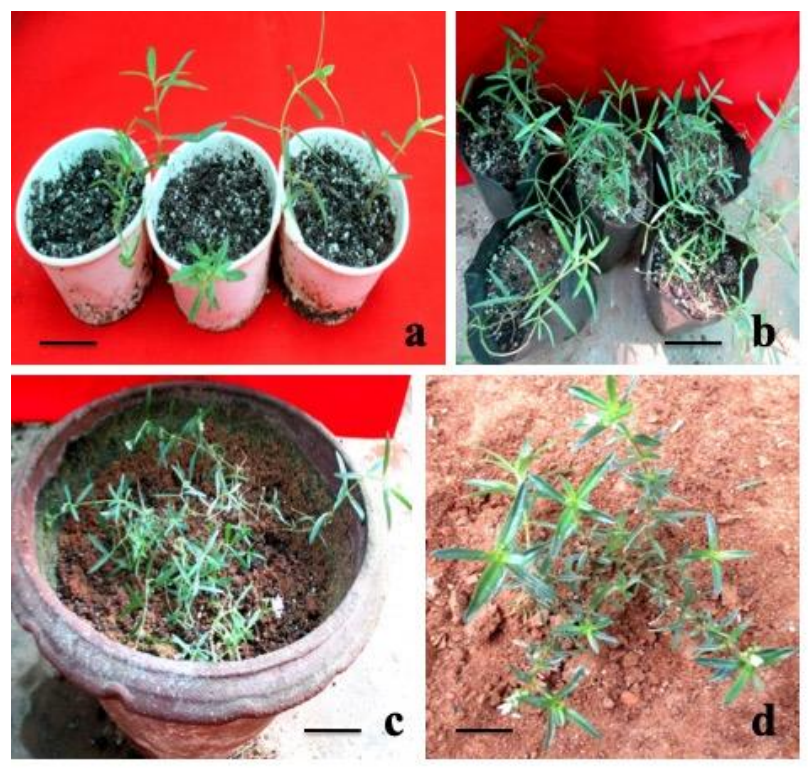

Figure 2. Hardening of plantlets of $O$. umbellata. (a) Hardening of plantlets in paper cups (containing soilrite ${ }^{\circledR}$ ) in greenhouse after 5 weeks, $(\mathrm{b}$ and $\mathrm{c})$ Hardened plantlets in the nursery polybags (containing organic manure, sand and red soil $(1: 1: 1 ; \mathrm{w} / \mathrm{w}))$ and earthen pot (filled with garden soil, red soil and vermi-compost (2:2:1; w/w) after 4-5 weeks, (d) Field transferred plant of O. umbellata (6 months old). (Scale bar $-5 \mathrm{~cm}$ )

\section{CONCLUSION}

The cultures were established from the node explants of O. umbellata. The meristematic activity of axillary buds was activated by the liquid MS medium augmented with BAP. The shoots were further multiplied by lowering the concentration of cytokinin and addition of auxin (IAA) to the medium. Well-developed shoots were routed by in vitro and ex vitro methods. Comparatively, IBA proved better for induction of roots than other auxins. The present protocol could be implemented for the large-scale production of 
plantlets of O. umbellata with less input of cost as compared to the semisolid medium.

\section{ACKNOWLEDGEMENTS}

Authors are grateful to the Department of Science, Technology and Environment, Government of Puducherry, India for providing financial support to their laboratory under the Grant-In-Aid Scheme.

\section{REFERENCES}

AlKhateeb, A. A. \& Alturki, S. M. 2014. A comparison of liquid and semi-solid cultures on shoot multiplication and rooting of three date palm cultivars (Phoenix dactylifera L.) in vitro. Advances in Environmental Biology 8(16): 263-269.

Babbar, S. B. \& Jain, R. 2006. Xanthan gum: an economical partial substitute for agar in microbial culture media. Current Microbiology 52: 287-292.

Behera, S. K., Rajasekaran, C., Payas, S., Fulzele, D. P., Doss, C. G. P., \& Siva, R. 2017. In vitro flowering in Oldenlandia umbellata L. Journal of Ayurveda and Integrated Medicine.

Cheruvathur, M. K., Abraham, J., \& Thomas, T. D. 2015. In vitro micropropagation and flowering in Ipomoea sepiaria Roxb. An important ethanomedicinal plant. Asian Pacific Journal of Reproduction 4: 49-53.

Compton, M. E. \& Mize, C. W. 1999. Statistical considerations for in vitro research: I - Birth of an idea to collecting data. In vitro Cellular \& Developmental Biology-Plant 35: 115.

Krishnan, S. R. S. \& Siril, E. A. 2015. Enhanced in vitro shoot regeneration in Oldenlandia umbellata L. by using quercetin: a naturally occurring auxin-transport inhibitor. Proceedings of National Academy of Sciences, India-Section B: Biological Sciences.

Krishnan, S. R. S. \& Siril, E. A. 2017. Auxin and nutritional stress coupled somatic embryogenesis in Oldenlandia umbellata L. Physiology and Molecular Biology of Plants.

Krishnan, S. R. S. \& Siril, E. A. 2016. Elicitor and precursor mediated anthraquinone production from cell suspension cultures of Oldenlandia umbellata L. International Journal of Pharmaceutical Science and Research 7: 3649-3657.

Kumar, N. V., Rani, M. E., Gunaseeli, R., \& Kannan, N. D. 2014. Rapid in vitro propagation of Oldenlandia umbellata L. - a dye yielding plant. Proceedings of National Symposium: Emerging Trends in Biotechnology 131-139.

Kuria, P., Demo, P., Nyende, A. B., \& Kahangi, E.M. 2008. Cassava starch as an alternative cheap gelling agent for the in vitro micro-propagation of potato (Solanum tuberosum L.). African Journal of Biotechnology 7: 301-307.

Mehta, M., Ram, R., \& Bhattacharya, A. 2014. A simple and cost effective liquid culture system for the micropropagation of two commercially important apple rootstocks. Indian Journal of Experimental Biology 52: 748-754.

Mohamed, M. A. H., Alsadon, A. A., \& Al Mohaidi, M. S. 2010. Corn and potato starch as an agar alternative for Solanum tuberosum micro-propagation. African Journal of Biotechnology 9: 12-16.

Murashige, T. \& Skoog, F. 1962. A revised medium for rapid growth and bioassays with Tobacco tissue culture.
Physiologia Plantarum 15: 473-497.

Patel, A. K., Phulwaria, M., Rai, M. K., Gupta, A. K., Shekhawat, S., \& Shekhawat, N. S. 2014. In vitro propagation and ex vitro rooting of Caralluma edulis (edgew.) benth.\&hook. f. An endemic and endangered edible plant species of the Thar desert. Scientia Horticulturae 165: 175-180.

Pati, P. K., Sharma, M., Sood, A., \& Ahuja, P. S. 2005. Micropropagation of Rosa damascena and R. bourboniana in liquid cultures. In: Liquid Culture Systems for in vitro Plant Propagation. Ed. Hvoslef-Eide, A.K. and Preil, W. pp. 373385. Springer: Dordrecht.

Ranaweeraa, K. K., Gunasekarab, M. T. K.. \& Eeswara, J. P. 2013. Ex vitro rooting: A low cost micropropagation technique for Tea (Camellia sinensis (L.) O. Kuntz) hybrids. Scientia Horticulturae 155: 8-14.

Samy, R. P., Thwin, M. M., Gopalakrishnakone, P., \& Ignacimuthu, S. 2008. Ethnobotanical survey of folk plants for the treatment of snakebites in Southern part of Tamilnadu, India. Journal of Ethnopharmacology 115: 302-312.

Shekhawat, M. S., Kannan, N., Manokari, M., \& Revathi, J. 2012. In vitro propagation of Oldenlandia umbellata L. - a highly medicinal \& dye-yielding plant of Coromandel coast. International Journal of Recent Scientific Research 3:758-761.

Siva, R., Mayes, S., Behera, S. K., \& Rajasekaran, C. 2012. Anthraquinones dye production using root cultures of Oldenlandia umbellata L. Industrial Crops and Production 37: 415 419.

Siva, R. 2007. Status of natural dyes and dye yielding plants in India. Current Science 92: 916-925.

Siva, R., Rajasekaran, C., \& Mudgal, G. 2009. Induction of somatic embryogenesis and organogenesis in Oldenlandia umbellata L., a dye-yielding medicinal plant. Plant Cell Tissue and Organ Culture 98: 205-211.

Takatsuka, H. \& Umeda, M. 2014. Hormonal control of cell division and elongation along differentiation trajectories in roots. Journal of Experimental Botany 65: 2633-2643.

Taylor, N. J., Light, M. E., \& Staden, J. V. 2005. In vitro flowering of Kniphofia leucocephala: influence of cytokinins. Plant Cell Tissue and Organ Culture 83: 327-333.

Thakur, M., Soni, M., Sharma, D. P. et al., 2018. In vitro propagation of Plum (Prunus salicina) cv. 'Santa Rosa' and assessment of genetic stability using RAPD markers. Indian Journal of Plant Physiology 23: 161.

The Plant List. 2013. Version 1.1. Published on the Internet. http://www.theplantlist.org/ (accessed 14 January 2019).

Yoganarasimhan, S. N. and Chelladurai, V. 2000. Medicinal Plants of India.. Bangalore: India, pp. 262.

Zeevaart, J. A. D. 2006. Florigen coming of age after 70 years. Plant Cell 18: 1783-1789. 